\title{
EKSISTENSI PTUN SEBAGAI WUJUD PERLINDUNGAN HUKUM KEPADA WARGA NEGARA DARI SIKAP TINDAK ADMINISTRASI NEGARA
}

\author{
Murtiningsih, \\ Adi Kusyandi \\ Universitas Wiralodra \\ Email: murti.kartini76@gmail.com,ak2633@gmail.com
}

\begin{abstract}
All actions that harm everyone can be monitored by the court, while the review can be channeled through the State Administrative Court (PTUN). The State Administrative Court is one of the implementers of judicial power for the people seeking justice for State Administrative disputes. PTUN aims to resolve State Administrative disputes. Research methods in this papers using normative juridical research methods and using data collection techniques carried out using descriptive analysis techniques, with secondary data sources, which include primary legal materials such as laws and regulations relating to the rights of children and wives in divorce cases, sued unseen husbands, as well as secondary legal materials such as books, journals, articles, and other legal doctrines. State administrative disputes are disputes that arise in the field of State Administration between Persons or Civil Legal Entities and Legal Entities or State Administration Officials, both at the center and in the regions, as a result of the issuance of State Administrative Decrees, including employment disputes based on statutory regulations applicable. With the juridical analysis method, the author discusses the existence of PTUN as a form of legal protection for citizens from the act of state administration (abuse of power)
\end{abstract}

Keywords: State Administrative Court, Legal Protection, Attitude of State Administration

\section{PENDAHULUAN}

Mewujudkan kesejahteraan umum bagi seluruh rakyat Indonesia adalah cita-cita yang menjadi perekat dan pemersatu bagi rakyat Indonesia yang memiliki tingkat prularisme yang tinggi. Cita-cita mulia tersebut tidak hanya menjadi kata-kata mutiara penghias UUD semata, namun cita-cita luhur tersebut harus terwujud dalam setiap aspek kehidupan rakyat Indonesia. Namun bukanlah suatu hal yang mudah untuk mewujudkan keinginan tersebut, butuh kerja keras dan kerjasama dari seluruh masyarakat Indonesia dan tentunya oleh Pemerintah.

Dalam rangka untuk mencapai cita-cita luhur tersebut founding father telah merumuskan prinsip dasar bernegara yang dituangkan dalam UUD 1945 (setelah 
perubahan ke-IV) selanjutnya disebut UUD 1945 (perubahan). Prinsip dasar tersebut antara lain : Prinsip Demokrasi Negara Hukum Pasal 1 ayat (2) UUD 1945 berbunyi "Kedaulatan berada ditangan rakyat dan dilaksanakan menurut Undang-undang Dasar", selanjutnya Pasal 1 ayat (3) UUD 1945 berbunyi "Negara Indonesia adalah negara hukum". Dua ketentuan pasal tersebut yang akan menjadi pondasi dan pedoman mencapai kesejahteraan bagi seluruh rakyat Indonesia.

Salah satu ciri dalam Konsep Negara Hukum baik dalam pengertian (rule of law ataupun rechstaat) adalah adanya Peradilan Administrasi Negara sebagaimana yang dikemukakan oleh $J . S t a h l^{1}$ yang kemudian di Indonesia dikenal dengan istilah Peradilan Tata Usaha Negara (PTUN), kehadiran PTUN tersebut memberikan angin segar bagi para pencari keadilan khususnya berkaitan dengan persoalan Administrasi Negara, namun hadirnya PTUN bukanlah tanpa masalah, hal ini terbukti banyakanya persoalan yang telah diputuskan oleh PTUN namun tidak berakhir sesuai harapan, lebih dari itu masih banyak masyarakat yang mengalami ketidakadilan oleh Pejabat Administrasi Negara yang tidak menyelesaikan persoalannya ke PTUN namun malah memilih tidak mengajukan persoalannya. Keadaan demikian memperlihatkan bahwa sesungguhnya keberadaan atau eksistensi Peradilan Tata Usaha Negara untuk memberikan perlindungan Kepada Warga Negara dari Sikap Tindak Administrasi Negara, masih diragukan.

\section{IDENTIFIKASI MASALAH}

Berdasarkan uraian Latar Belakang tersebut, maka dapat dirumuskan identifikasi permasalahan sebagai berikut: Bagaimanakah Eksistensi Peradilan Tata Usaha Negara dalam rangka memberikan Perlindungan Hukum Terhadap sikap Tindak administrasi Negara?

\section{METODE}

Metode penelitian yang dipergunakan dalam penulisan ini adalah dengan yuridis normatif, yaitu melakukan penelitian terhadap peraturan perundang-undangan dan berbagai literatur yang berkaitan dengan penulisan. Tekhnik pengumpulan data yang menggunakan studi kepustakaan (library resreach) yaitu melakukan penelitian terhadap berbagai sumber bacaan seperti buku-buku, pendapat sarjana, bahan kuliah, surat kabar, artikel dan juga

\footnotetext{
${ }^{1}$ Azhary, Negara Hukum Indonesia, Analisis Yuridis Normatif tentang Unsur-unsurnya, Penerbit UI Press, Jakarta 1995 hlm. 46.
} 


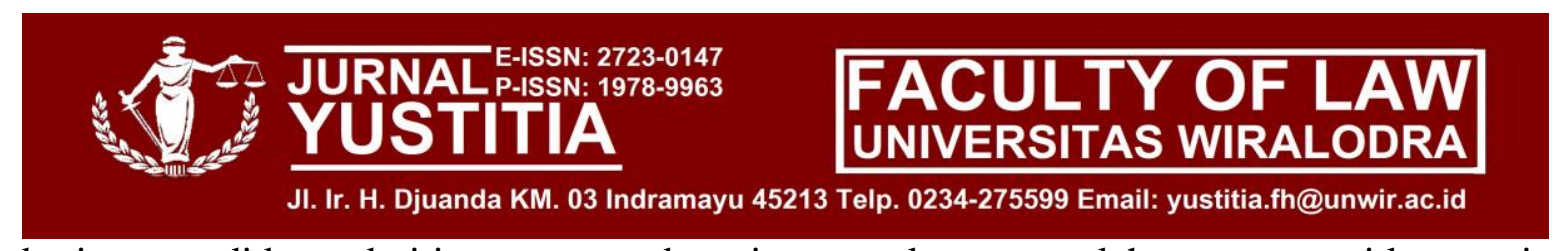

berita yang didapat dari internet yang bertujuan untuk memperoleh atau mencari konsepsikonsepsi, teori-teori atau bahan-bahan atau doktrin-doktrin yang berkenaan dengan penulisan ini, dimana data yang diapakai adalah analisis kualitatif yaitu data yang didapat secara primer maupun sekunder disusun dengan sistematis kemudian disimpulkan sehingga diperoleh gambaran yang jelas.

Landasan Teoritis yang dipakai adalah menggunakan konsep Negara Kesejahteraan (welfare state) atau dikenal dengan istilah negara hukum modern, adalah suatu konsep dimana tugas utama sebuah negara adalah untuk mensejahterakan seluruh rakyatnya. Dalam kondisi demikian maka tugas pemerintah diperluas dengan maksud untuk menjamin kepentingan umum sehingga lapangan tugasnya mencakup berbagai aspek yang semula menjadi urusan masyarakat seperti masalah kesehatan rakyat, pendidikan, perumahan, distribusi tanah dan sebagainya. Jadi didalam konsep welfare state pemerintah itu diserahi bestuurzorg yaitu penyelenggaraan kesejahteraan umum².

Untuk menjalankan tugasnya menyelenggarakan kesejahteraan umum itu pemerintah diberi juga Freis Ermessen, yaitu kewenangan yang sah untuk turut campur dalam kegiatan sosial guna melaksanakan tugas-tugas menyelenggarakan kepentingan umum itu, seperti memberi izin, melalukan pencabutan hak (onteigening), mendirikan rumah sakit, sekolah, perusahaan dan sebagainy ${ }^{3}$. Singkatnya Freis Ermerssen memberikan kebebasan kepada Administrasi Negara untuk bertindak atas inisiatif sendiri melakukan perbuatan-perbuatan guna menyelesaikan persoalan-persoalan yang mendesak dengan cepat guna kepentingan umum/kesejahteraan umum ${ }^{4}$. Pemberian Freis Ermerssen kepada Administrasi Negara tidak boleh digunakan tanpa batas dan tidak boleh disalahgunakan. Pemerintah dilarang melakukan tindakan-tindakan yang bersifat dokument de pouvoi atau onrechtmatige overheidsdaad (perbuatan melawan hukum oleh penguasa). Singkatnya Freis Ermessen harus dijalankan dalam kerangka Negara Hukum.

Sebelum perubahan UUD 1945 ditegaskan dalam Penjelasan UUD 1945 bahwa: "Negara Indonesia berdasar atas Hukum (Rechtstaat)", sehingga dari penjelasan tersebut mempertegas bahwa negara hukum Indonesia adalah negara hukum yang menganut konsep Rechstaat. Menurut Julius Sthal, konsep negara hukum yang disebut dengan istilah

\footnotetext{
2 SF.Marbun \& Moh.Mafud MD, Pokok-pokok Hukum Administrasi Negara, Cet III Liberty Yogyakarta 2004, hlm. 45.

3 Ibid, hlm. 46.

4 Bega Ragawindo, Hukum Administrasi Negara, Bandung 2010, hlm. 40.
} 


\section{TURNALE-ISSN: 2723-0147

rechstaat itu mencakup 4 elemen penting, yaitu : 1. Perlindungan Hak Asasi Manusia; 2.

Pembagian Kekuasaan; 3. Pemerintahan berdasarkan undang-undang; 4. Peradilan Tata Usaha Negara ${ }^{5}$. Konsep rechstaat biasa dilawankan dengan konsep Rule of The Law. A.V.Dicey menguraikan adanya 3 ciri penting dalam setiap negara hukum rule of the law, yaitu: 1.Supermacy of Law; 2. Equality before the law; 3. Due Process of Law.

\section{HASIL DAN PEMBAHASAN}

\section{A. Sikap Tindak Administrasi Negara (Perbuatan/tindakan pemerintah) dan Peradilan Tata Usaha Negara}

Dalam melaksanakan tugas menyelenggarakan kepentingan umum, pemerintah banyak melakukan kegiatan atau perbuatan-perbuatan. Aktivitas atau perbuatan itu pada garis besarnya dibedakan ke dalam 2 golongan, yaitu: ${ }^{6}$

1. Rechts handeligen (golongan perbuatan hukum);

2. Feitlijke handeligen (golongan yang bukan perbuatan hukum).

Kedua golongan perbuatan tersebut yang penting bagi Hukum Administrasi Negara adalah golongan perbuatan hukum (recht handeligen), sebab perbuatan tersebut langsung menimbulkan akibat hukum tertentu bagi Hukum administrasi Negara ${ }^{7}$. Perbuatan pemerintah yang termasuk golongan perbuatan hukum dapat berupa: 1. Perbuatan pemerintah dalam lapangan hukum privat; dan 2. Perbuatan pemerintah dalam lapangan hukum publik ${ }^{8}$.

Apabila kita melihat dampak suatu keputusan terhadap orang, yang kepadanya keputusan itu ditunjukan, maka kita dapat membuat pembagian sebagai berikut: ${ }^{9}$

a. Keputusan dalam rangka ketentuan-ketentuan larangan dan/atau perintah ( $\mathrm{gebod}$ );

b. Keputusan-keputusan yang menyediakan sejumlah uang;

c. Keputusan-keputusan yang membebankan suatu kewajiban keuangan;

d. Keputusan-keputusan yang memberikan suatu kedudukan;

e. Keputusan penyitaan.

\footnotetext{
5 Jimmly Ashidiqie, Pokok-Pokok Hukum Tata Negara Indonesia Pasca Reformasi, Bhuana Ilmu Populer Jakarta, hlm. 304

6 E. Utrech, Pengantar Hukum administrasi Negara Indonesia, Fakultas Hukum dan Pengetahuan Masyarakat Unpad, Bandung 1960, hlm. 63

7 Ibid, MF Marbun dan Mafud MD, hlm. 68.

8 Fauzul, Tindakan pemerintah Fakultas Hukum UPN, Jawa Timur 2009, hlm. 18.

9 Ibid, hlm. 126.
} 


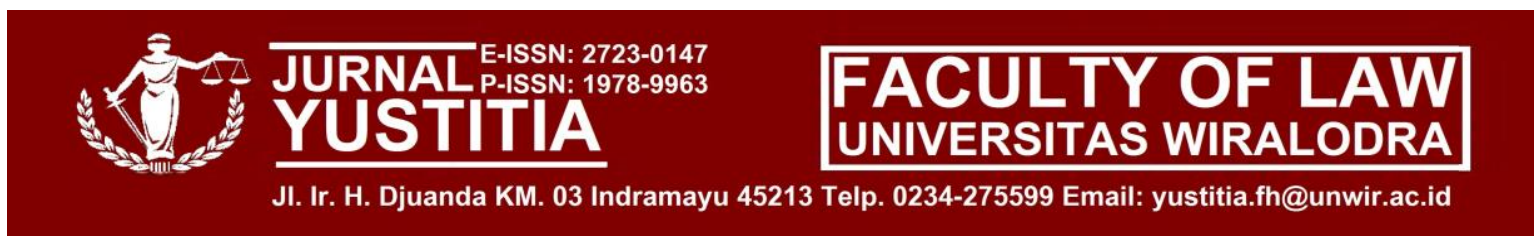

Berbagai keputusan diatas, tidak menutup kemungkinana disalahgunakan atau terjadi kesalahan baik disengaja atau tidak disengaja. Kesalahan yang terjadi tentunya dapat mengakibatkan kerugian bagi masyarakat. Oleh karena itu untuk melindungi masyarakat atau pejabat administrasi negara dari tindakan kesewang-wenangan, dari penguasa (pemerintah) diperlukan suatu upaya untuk melindunginya, khususnya melindungi masyarakat/pejabat administrasi dari keputusan-keputusan yang sifatnya dirasa merugikan atau bertentangan dengan hukum. Wujud dan usaha perlindungan tersebutlah kemudian yang melahirkan suatu Perdilan Tata Usaha Negara (PTUN) yakni sebuah peradilan yang didirikan untuk menyelesaikan sengketa yang timbul dalam bidang Tata Usaha Negara antara Orang atau Badan Hukum Perdata dengan Badan atau Pejabat Tata Usaha Negara, baik di pusat maupun di daerah, sebagai akibat dikeluarkannya Keputusan Tata Usaha Negara ${ }^{10}$.

Di Indonesia Peradilan Tata Usaha Negara diatur dalam Undang-undang No. 51 Tahun 2009 tentang Perubahan atas UU No. 5 Tahun 1986 tentang Peradilan Tata Usaha Negara. Kedua undang-undang inilah yang mengatur segala perihal yang berkaitan dengan Peradilan Tata Usaha Negara. berdirinya Peradilan Tata Usaha Negara (PTUN) diadakan dalam rangka memberikan perlindungan (berdasarkan keadilan, kebenaran, ketertiban dan kepastian hukum) kepada rakyat pencari keadilan (justiciabelen) yang merasa dirinya dirugikan akibat suatu perbuatan hukum oleh pejabat administrasi negara, melalui pemeriksaan, pemutusan dan penyelesaian sengketa dalam bidang administrasi negara sekaligus memperkokoh prinsip negara hukum modern (welfare state) yang salah satu ciricirinya sebagaimana diutarakan oleh Prof, Jimly Ashidiqie yakni tersedianya Peradilan Tata Usaha Negara.

\section{B. Eksistensi Peradialn Tata Usaha Negara Dalam Rangka Memberikan Perlindungan Hukum Terhadap Sikap Tindak Administrasi Negara}

Menurut Friedich Julian Sthal, di negara hukum secara formal pada asasnya dan pada umumnya segala perbuatan yang merugikan setiap orang dapat diawasi pengadilan, sedangkan review-nya dapat disalurkan melalui Pengadilan Tata Usaha Negara (PTUN). PTUN merupakan sarana control on the administration ${ }^{11}$.

\footnotetext{
${ }^{10}$ Rochmat Soemitro, Peradilan Tata Usaha Negara, Refika Aditama Bandung 1987, hlm. 6.

${ }^{11}$ A. Siti Soetami, Hukum Acara Peradilan Tata Usaha Negara, Cet ke-V (edisi revisi), reflika Aditama Bandung 2007, hlm. 9.
} 


\section{(1)

Keberadaan Peradialn Tata Usaha Negara di Indonesia memiliki landasan Konstitusional yakni Pasal 24 ayat (2) UUD 1945 (perubahan) yang berbunyi : "Kekuasaan kehakiman dilakukan oleh sebuah Mahkamah Agung dan badan peradilan yang berada dibawahnya dalam lingkungan peradilan umum, lingkungan peradilan agama, lingkungan peradilan militer, lingkungan peradilan tata usaha negara dan oleh sebuah Mahkamah Konstitusi”.

Dengan diaturnya PTUN dalam UUD 1945 maka secara yuridis PTUN memiliki dasar hukum yang kuat. Sebagai pelaksanaannya PTUN kemudian diatur lebih lanjut dalam UU No.5 Tahun 1986 jo UU No.9 Tahun 2004. Peradilan Tata Usaha Negara Adalah salah satu pelaksana kekiasaan kehakiman bagi rakyat pencari keadilan terhadap sengketa Tata Usaha Negara ${ }^{12}$. Kekuasaan Kehakiman di lingkungan Peradilan Tata Usaha Negara dilaksanakan oleh: 1. Pengadilan Tata Usaha Negara; 2. Pengadilan Tinggi Tata Usaha Negara, yang akhirnya Peradilan ini berpuncak pada Mahkamah Agung.

PTUN bertujuan untuk menyelesaikan sengketa Tata Usaha Negara. Sengketa Tata Usaha Negara adalah sengketa yang timbul dalam bidang Tata Usaha Negara antara Orang atau Badan Hukum Perdata dengan Badan Hukum atau Pejabat Tata Usaha Negara, baik dipusat maupun di daerah, sebagai akibat dikeluarkannya Keputusan Tata Usaha Negara, termasuk sengketa kepegawaian berdasarkan peraturan perundang-undangan yang berlaku ${ }^{13}$. Jadi jelas yang menjadi titik tolak sengketa adalah "Keputusan Tata Usaha Negara." Keputusan Tata Usaha Negara adalah suatu penetapan tertulis yang dikeluarkan oleh Badan atau Pejabat Tata Usaha Negara yang berisi tindakan Hukum Tata Usaha Negara yang berdasarkan peraturan perundang-undangan yang berlaku, yang bersifat konkret, individual, dan final, yang menimbulkan akibat hukum bagi seseorang atau Badan Hukum Perdata ${ }^{14}$. Keputusan Tata Usaha Negara adalah berupa suatu "Penetapan Tertulis". Penetapan tertulis diartikan luas oleh UU dan bukan menunjuk kepada bentuk formalnya, melainkan cukup tertulis. Pernyataan tertulis ini diharuskan untuk memudahkan pembuktiannya. Oleh karena itu sebuah memo atau nota tertulis sudah dianggap memenuhi syarat Keputusan Badan atau Pejabat Tata Usaha Negara, menurut UU ini apabila:

1. Badan atau Pejabat TUN yang mengeluarkannya;

2. Maksud dan isi tulisan itu, yang mempunyai akibat menimbulkan hak dan kewajiban;

\footnotetext{
${ }^{12}$ Pasal 4 UU No.5 Tahun 1986

${ }^{13}$ Pasal 1 ayat (4) UU No. 5 Tahun 1986

${ }^{14}$ Pasal 1 ayat (3) UU No. 5 Tahun 1986
} 
3. Kepada siapa tulisan itu ditunjukan (bersifat individual dan konkret).

\section{a. Para Pihak Dalam Sengketa TUN}

Sebagaimana yang diuraikan diatas bahwa Sengketa Tata Usaha Negara adalah sengketa yang timbul dalam bidang Tata Usaha Negara antar Orang atau Badan Hukum Perdata dengan Badan atau Pejabat Tata Usaha Negara, baik dipusat maupun didaerah, sebagai akibat dikeluarkannya Keputusan Tata Usaha Negara, termasuk sengketa kepegawaian berdasarkan peraturan perundang-undangan yang berlaku. Dari hal ini jelas bagi kita bahwa yang dapat digugat di pengadilan pada lingkungan peradilan hukum tata usaha negara adalah badan atau pejabat tata usaha negara inilah yang dapat mengeluarkan Surat Keputusan Tata Usaha Negara. Sedangkan yang berhak mengugat atau yang menjadi penggugat ialah orang atau badan hukum perdata, yang merasa dirugikan karena dikeluarkannya suatu keputusan tata usaha negara. Karena sengketa tata usaha negara tersebut selalu berkaitan dengan dikeluarkannya suatu keputusan tata usaha negara, maka satu-satunya pihak yang dapat di gugat pada PTUN adalah Badan atau Pejabat Tata Usaha Negara. Berdasarkan hal ini maka dalam Acara PTUN tidak dikenal adanya gugatan rekonveksi atau dengan kata lain seorang pejabat tata usaha negara yang merasa dirugikan baik moril maupun materil karena adanya gugatan dari warga masyarakat atau badan hukum perdata, tidak dapat mengajukan gugatan balik atau rekonveksi.

\section{b. Dasar Pengujian Keputusan Tata Usaha Negara}

Dari ketentuan pasal 53 ayat (2) yang sudah diubah dengan UU No. 9 Tahun 2004, dapat diketahui bahwa Keputusan Tata Usaha Negara akan dinyatakan batal atau tidak sah, jika:

1. Keputusan Tata Usaha Negara yang digugat itu bertentangan dengan peraturan perundang-undangan yang berlaku;

2. Keputusan Tata Usaha Negara yang digugat itu bertentangan dengan asas-asas umum pemerintahan yang baik.

Adapun asas-asas pemerintahan yang baik, dapat dilihat pada pasal 3 UU No.28 Tahun 1999, yakni:

> Asas kepastian hukum;

$>$ Asas Tertib Penyelenggara Negara;

$>$ Asas Kepentingan Umum;

> Asas keterbukaan; 
$>$ Asas proposionalitas;

$>$ Asas profesionalitas;

$>$ Asas akuntabilitas.

\section{c. Penyelesaian Sengketa Tata Usaha Negara}

Menurut Undang-undang No. 5 Tahun 1985 Jo Undang-undang No. 9 Tahun 2004 tentang Peradilan Tata Usaha Negara. Untuk menyelesaikan sengketa Tata Usaha Negara yang timbul sebagai akibat diterbitkannya suatu Keputusan Tata Usaha Negara (beschiking) dapat dilakukan melalui 2 cara yaitu:

1. Melalui upaya administrasi; dan

2. Melalui gugatan.

Add 1. Melalui Upaya Administrasi

Menurut penjelasan pasal 48 UU No. 5 Tahun 1986 jo UU No. 9 Tahun 2004 tentang Peradilan Tata Usaha Negara, upaya administrasi adalah merupakan prosedur yang ditentukan dalam suatu peraturan perundang-undangan untuk menyelesaikan suatu sengketa Tata Usaha Negara yang dilaksanakan dilingkungan pemerintah sendiri (bukan oleh badan peradilan yang bebas), yang terdiri dari : 1. Prosedur Keberatan; dan 2. Prosedur Banding Administratif.

Berdasarkan rumusan penjelasan pasal 48 tersebut maka upaya administrasi merupakan sarana perlindungan hukum bagi warga masyarakat (orang perorangan/ badan hukum perdata) yang terkena Keputusan Tata Usaha Negara dilingkungan pemerintah itu sendiri sebelum diajukan ke badan peradilan.

Pasal 48 menentukan : (1) Dalam hal suatu Badan atau Pejabat Tata Usaha Negara diberi wewenang oleh atau berdasarkan peraturan perundang-undangan untuk menyelenggarakan secara administratif sengketa Tata Usaha Negara tertentu, maka batal atau tidak sah, dengan atau tanpa disertai tuntutan ganti rugi dan/atau administratif yang tersedia; (2) Peradilan baru berwenang memeriksa, memutus, dan menyelesaikan sengketa Tata Usaha Negara sebagaimana dimaksud dalam ayat (1) jika seluruh upaya administratif yang bersangkutan telah digunakan. Dari ketentuan tersebut dapat diambil beberapa hal penting yakni:

a. Dengan dipergunakan kalimat "sengketa tata usaha negara tertentu", maka penyelesaian sengketa TUN melalui upaya administrasi tidak berlaku untuk semua 
sengketa TUN, tetapi hanya sengketa yang penyelesaiannya tersedia upaya administratif saja;

b. Pengadilan dilingkungan PTUN baru mempunyai wewenang untuk memeriksa, memutuskan, dan menyelesaikan sengketa TUN yang tersedia upaya administratif, jika seluruh uapaya administrasi tersebut telah digunakan dan mendapatkan keputusan.

Untuk mengetahui penyelesaian sengketa TUN itu tersedia upaya administratif, dapat diperhatikan pada peraturan perundang-undangan yang menjadi dasar hukum dikeluarkannya Keputusan TUN yang mengakibatkan terjadinya sengketa TUN tersebut ${ }^{15}$.

Dari penjelasan pasal 48 ayat (1) dapat diketahui bentuk dari upaya administrasi dapat berupa:

1. Keberatan

Yaitu prosedur yang ditempuh oleh seseorang atau Badan Hukum Perdata yang tidak puas terhadap KTUN yang penyelesaian sengketa TUN sebagai akibat dikeluarkannya KTUN tersebut dilakukan sendiri oleh Badan atau Pejabat TUN yang mengeluarkan KTUN yang dimaksud;

2. Banding Administrasi

Yaitu prosedur yang ditempuh oleh seseorang atau Badan Hukum Perdata yang tidak puas terhadap KTUN, yang penyelesaian sengketa TUN sebagai akibat dikeluarkannya KTUN tersebut, dilakukan oleh atasan dari badan atau Pejabat TUN yang mengeluarkan KTUN atau instansi lain dari Badan atau pejabat TUN yang mengeluarkan KTUN.

Penyelesaian melalui upaya administrasi tentunya diharapkan memberikan solusi dari persoalan terhadap sengketa pada KTUN, namun persoalan bagaimana jika persoalan tersebut tidak terselesaikan baik pda upaya administratif berupa keberatan atau banding administratif. Terhadap persoalan ini kita dapat merujuk dengan SEMA No.2 tahun 1991 tentang Petunjuk Pelaksanaan Ketentuan Dalam Undang-undang No.5 Tahun 1986 tentang Peradilan Tata Usaha Negara. Terdapat ketentuan dalam SEMA ini jika orang atau badan hukum perdata masih belum puas terhadap keputusan dari upaya administratif yang telah diajukan maka:

1. Jika dalam peraturan perundang-undangan yang menjadi dasar dikeluarkannya KTUN yang mengakibatkan terjadinya sengketa TUN upaya administrasi yang tersedia

\footnotetext{
${ }^{15}$ R.Wiyono Hukum Peradila Tata Usaha Negara. Edisi ke II. Sinar Grafika Jakarta 2008, hlm. 109.
} 
keberatan, maka penyelesian selanjutnya adalah dengan mengajukan gugatan ke Pengadilan TUN;

2. Jika dalam peraturan perundang-undangan yang menjadi dasar dikeluarkannya KTUN yang mengakibatkan terjadinya sengketa TUN, upaya administrasi yang tersedia adalah banding administratif atau keberatan dan banding administratif, maka penyelesian selanjutnya adalah dengan mengajukan gugatan ke Pengadilan Tinggi TUN.

Diaturnya upaya sdministrasi dimaksudkan sebagai kontrol atau pengawasan yang bersifat intern dan represif di lingkungan TUN terhdap keputusan yang dikeluarkan oleh Badan atau Pejabat TUN.

Add 2. Melalui Upaya Gugatan

Adapun yang dimaksud dengan gugatan dalam penyelesaian sengketa TUN adalah permohonan secara tertulis dari seseorang atau badan hukum perdata yang merasa kepentingannya dirugikan oleh suatu keputusan TUN, yang ditunjukan kepada Pengadilan di Lingkungan Peradilan TUN, yang berisi tuntutan agar KTUN tersebut dibatalkan atau tidak sah dengan atau tanpa disertai tuntutan ganti rugi dan/atau rehabilitasi ${ }^{16}$.

Adapun sengketa TUN yang diselesaikan melalui gugatan adalah sebagai berikut:

1. Sengketa TUN yang penyelesainnya tidak tersedia upaya administratif;

2. Sengketa TUN yang penyelesainnya sudah melalui upaya administratif yang tersedia (keberatan dan/atau banding administratif), akan tetapi terhadap keputusan tersebut orang atau badan hukum perdata yang merasa dirugikan dengan dikeluarkannya KTUN masih belum dapat menerimanya.

Adapun syarat-syarat yang harus dimuat dalam surat gugatan antara lain:

1. Identitas dari :

$>$ Penggugat;

$>$ Tergugat.

2. Dasar Gugatan (fundamental fetendi/ posita/dalil penggugat);

3. Hal-hal yang diminta untuk diputus oleh pengadilan (petitum).

Hal yang tidak kalah pentingnya adalah tenggang waktu gugatan, karena jika tenggang waktu melewati masa batas akhir gugatan maka pengadilan mempunyai alasan untuk memutuskan dengan penetapan bahwa gugatan tidak dapat diterima atau tidak

\footnotetext{
${ }^{16}$ Pasal 53 ayat (1) UU No. 9 Tahun 2004
} 
berdasar. Dalam sengketa TUN gugatan hanya dapat diajukan dalam tenggang waktu 90 hari terhitung sejak saat diterimanya atau diumumkannya Keputusan Badan atau Pejabat TUN yang digugat.

\section{d. Pemeriksaan Sidang Pengadilan Tingkat Pertama}

Pemeriksaan sidang tingkat pertama yang dilakukan oleh:

1. PTUN untuk semua sengketa TUN sebagai berikut :

a. Yang tidak disediakan upaya administratif, baik berupa keberatan maupun banding administratif;

b. Yang telah mendapatkan keputusan melalui upaya administratif yang berupa kberatan;

c. PTUN untuk sengketa TUN yang telah mendapatkan keputusan melalui upaya administratif yang berupa banding administratif.

\section{e. Eksekusi Putusan Pengadilan}

Putusan yang dapat dieksekusi adalah hanya putusan pengadilan yang telah memperoleh kekuatan hukum tetap yang dapat dilaksanakan ${ }^{17}$. Adapun yang dimaksud dengan putusan yang telah mempunyai kekuatan hukum tetap, yaitu jika:

1. Penggugat dan Tergugat telah menyatakan menerima terhadap putusan pengadilan, padahal penggugat dan tergugat mempunyai hak untuk mengajukan permohonan pemeriksaan ditingkat banding;

2. Sampai lewat waktu yang telah ditentukan, penggugat dan tergugat tidak mengajukan permohonan pemeriksaan ditingkat banding atau kasasi.

Adapun yang berwenang mengawasi ekseskusi putusan pengadilan yang telah memperoleh kekuatan hukum tetap adalah Ketua Pengadilan. Yang dimaksud ketua pengadilan disini adalah ketua pengadilan yang mengadili sengketa TUN pada tingkat pertama.

Dari uraian diatas dapat dipahami bahwa PTUN adalah sebuah lembaga peradilan yang keberadaannya masih sangat diperlukan dalam rangka memberikan perlindungan kepada masyarakat dari tindakan administrasi negara yang semena-mena, bertentangan dengan peraturan perundang-undangan serta bertentangan dengan asas-asas pemerintahan yang baik (AUPB). Adapun upaya perlindungan hukum yang diatur dalam UU PTUN

\footnotetext{
${ }^{17}$ Pasal 115 UU No. 5 Tahun 1986
} 


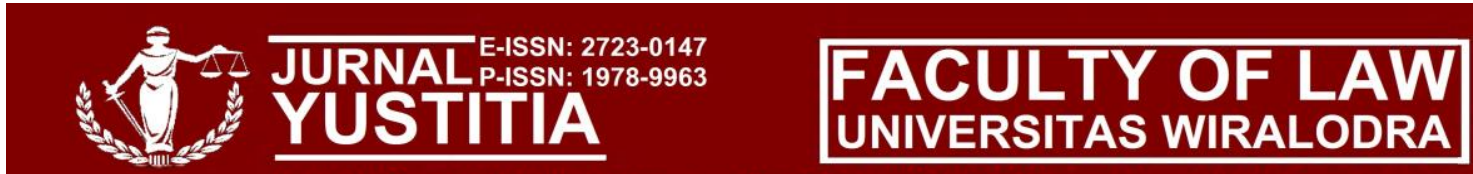

JI. Ir. H. Djuanda KM. 03 Indramayu 45213 Telp. 0234-275599 Email: yustitia.fh@unwir.ac.id

yakni ada 2 mekanisme: (1). Mekanisme Upaya Administratif; (2) Melalui Gugatan. Dapat diperkirakan bilamana PTUN ditiadakan, hal ini tentunya mengakibatkan sulitnya warga negara untuk memperjuangkan haknya serta memperoleh perlindungan dari tindakan administrasi negara yang menyimpang

\section{PENUTUP}

\section{A. Simpulan}

Eksistensi pengadilan TUN adalah selain sebagai salah satu ciri negara hukum modern (welfare state) juga memberikan perlindungan hukum kepada masyarakat serta aparatur pemerintahan itu sendiri karena PTUN melakukan kontrol yuridis terhadap perbuatan hukum publik, badan atau pejabat Administrasi Negara, namun sebelum sengketa TUN diajukan ke pengadilan TUN, maka penggugat harus terlebih dahulu memperhatikan ketentuan peraturan perundang-undangan yang terkait dengan sengketa yang akan ia ajukan, karena dalam beberapa sengketa mensyaratkan bahwa harus diselesaikan melalui upaya administrasi, yang terdiri atas: Pertama, Keberatan Administrasi; Kedua, Banding Administrasi. Setelah melaui upaya administrasi ini barulah sengketa TUN dapat diajukan ke Pengadilan TUN atau Pengadilan Tinggi TUN.

\section{B. Saran}

Keberadaan Peradilan Tata Usaha Negara (PTUN) masih diperlukan keberadaannya oleh para pihak (masyarakat) yang mencari keadilan secara admintrasi. Ekistensi kehadiran PTUN itu sendiri harus pula memenuhi rasa keadilan yang tidak sepihak serta harus dapat mewujudkan bentuk perlindungan masyarakat yang berkesejahteraan atas tindak administrasi negara yang baik.

\section{DAFTAR PUSTAKA}

\section{A. Buku :}

A Siti Soetami. Hukum Acara Peradilan Tata Usaha Negara. Cet V (edisi revisi). Reflika Aditama Bandung 2007. 
Azhary. Negara Hukum Indonesia, Analisis Yuridis Normatif tentang Unsur-unsurnya,

UI Press Jakarta 1995.

Bega Ragawindo. Hukum Administrasi Negara. Bandung 2010.

E. Utrech. Pengantar Hukum Administrasi Negara. Fakultas Hukum dan Pengetahuan Masyarakat. Unpad Bandung 1960.

Fauzul. Tindakan Pemerintah. Fakultas Hukum UPN Jawa Timur 2009.

Jimly ashidiqie. Pokok-pokok Hukum Tata Negara Indonesia Pasca Reformasi. Bhuwana Ilmu Populer Jakarta 2009.

Philipus M.Hadjon \& Sri Soemantri. Pengantar Hukum Administrasi Indonesia, Cet VII. Gadjah Mada University Press. Yogyakarta 2001.

Pradjudi Atmosudirdjo. Hukum Administrasi Negara, Cet ke-9. Ghalia Indonesia. Jakarta 1988.

R.Wiyono. Hukum Acara Peradilan Tata Usaha Negara, Edisi II. Sinar Grafika. Jakarta 2008.

Rochmat Sumitro. Peradilan Tata Usaha Negara. Refika Aditama. Bandung 1987.

SF. Marbun \& Moh.Mafhud MD. Pokok-pokok Hukum Administrasi Negara, Cet III. Liberty. Yogyakarta 2004.

Sjachran Basah. Hukum Acara Pengadilan Tata Usaha Negara. Rajawali Press. Jakarta 1989.

\section{B. Undang-undang}

- Undang-Undang Dasar 1945

- Undang-Undang Nomor 5 Tahun 1986 Tentang Peradilan Tata Usaha Negara

- Undang-Undang Nomor 51 Tahun 2009 Tentang Perubahan Kedua Atas UndangUndang Nomor 5 Tahun 1986 Tentang Peradilan Tata Usaha Negara 